\title{
SEXUALLY TRANSMITTED INFECTIONS AMONG HIV PATIENTS IN ALBANIA
}

\author{
Erjona Shehu', Arjan Harxhi ${ }^{2}$, Artan Simaku ${ }^{3 *}$ \\ ${ }^{1}$ Dermatological Service, University Hospital Centre "Mother Theresa”, Tirana, Albania; \\ ${ }^{2}$ Infectious Diseases Service, University Hospital Centre "Mother Theresa”, Tirana, Albania; \\ ${ }^{3 *}$ Institute of Public Health, Tirana, Albania;
}

*Corresponding author Artan Simaku, email: $\underline{\operatorname{artan} . s i m a k u @ g m a i l . c o m ; ~}$

Received August, 2018; Accepted August, 2018; Published September, 2018;

DOI: https://doi.org/10.31407/ijees8419

UOI license: http://u-o-i.org/1.01/ijees/94646925

\begin{abstract}
Sexually transmitted infections (STI) are important health risks for people living with human immunodeficiency virus (HIV) infection in the era of combination antiretroviral therapy. This is a retrospective study including HIVpositive patients who referred to the Ambulatory Clinic for HIV/AIDS, at the Infective Service and Dermatology Service of University Hospital Centre (UHC) "Mother Theresa", Tirana, Albania over the period 2008 to 2015. The study included all cases of adult patients over 15 years diagnosed with HIV/AIDS infection associated with STI registered and attended by the outpatient clinic and the UHC Infectious Disease Service which is is the only national tertiary care center in Albania that treats HIV/AIDS patients all over the country. Overall, five hundred twenty one patients presents to the clinic and $115(22.1 \%)$ out of them were diagnosed with a STI (95\%CI $18.60-25.91$ ). Syphilis is the most common STI in 44 (38.8\%) followed by anal condyloma in 20 (17.4\%) of total patients. All such patients should be regularly screened and subsequently treated for prevalent and incident STIs. There should be emphasis on avoidance of high-risk sexual behavior that leads to increased STI acquisition.
\end{abstract}

Key words: infection, therapy, HIV, STT, patients. 